\title{
PENGARUH PERLAKUAN BENIH DENGAN Trichoderma viride dan Pseudomonas fluorescens TERHADAP KETERJADIAN PENYAKIT BULAI (Peronosclerospora maydis) PADA BERBAGAI VARIETAS JAGUNG (Zea mays L.)
}

\author{
Alexander Turnip, Efri \& Joko Prasetyo \\ Jurusan Agroteknologi, Fakultas Pertanian, Universitas Lampung \\ Jl. Soemantri Brodjonegoro No. 1 Bandar Lampung 35145
}

\begin{abstract}
ABSTRAK
Penyakit bulai (downy mildew) yang disebabkan oleh jamur Peronosclerospora maydis merupakan penyakit yang banyak merusak tanaman jagung dan dapat menimbulkan kehilangan hasil sampai $100 \%$. Salah satu alternatif pengendalian yang mulai dikembangkan saat ini adalah pemanfaatan agensia hayati. Trichoderma spp. dan bakteri Pseudomonas fluorescens memiliki potensi sebagai agensia hayati. Penelitian ini bertujuan mengetahui pengaruh jamur T. viride, bakteri P. fluorescens, dan kombinasi keduanya terhadap keterjadian penyakit bulai ( $P$. maydis) pada varietas jagung lokal, jagung hibrida, dan jagung manis melalui perlakuan benih. Hasil penelitian menunjukkan bahwa jamur $T$. viride, bakteri $P$. fluorescens, serta kombinasi keduanya tidak berpengaruh terhadap keterjadian penyakit bulai pada tanaman jagung melalui perlakuan benih. Namun perbedaan varietas jagung berpengaruh nyata terhadap keterjadian penyakit bulai, varietas lokal mempunyai sifat ketahanan yang lebih tinggi dibandingkan dengan varietas lainnya.
\end{abstract}

Kata kunci : Keterjadian penyakit, P. maydis, P. fluorescens, . viride.

\section{PENDAHULUAN}

Di Propinsi Lampung, rata-rata produksi jagung tahun 2010 mencapai 2,12 juta ton per hektar (Biro Pusat Statistik, 2010). Produksi ini dengan rata-rata produksi jagung di Indonesia yang mencapai 3,2 ton per hektar. Namun begitu, rata-rata produksi jagung ini ternyata lebih rendah bila dibandingkan produktivitas jagung di negaranegara maju yang rata-rata diatas 8 ton per hektar (Prabowo, 2005).

Rendahnya produktivitas jagung di Indonesia disebabkan adanya kendala berupa organisme pengganggu tanaman, yang meliputi hama dan penyakit. Penyakit yang banyak merusak tanaman jagung adalah bulai (downy mildew). Penyakit ini disebabkan oleh jamur Peronosclerospora maydis yang merusak daun jagung dan dapat menimbulkan kehilangan hasil sampai 100\%, seperti yang terjadi di Lampung pada tahun 1996 (Subandi et al., 1996 dalam Iriany et al., 2003).

Sejauh ini usaha pengendalian penyakit bulai pada tanaman jagung yang umum digunakan adalah perlakuan benih dengan menggunakan metalaksil. Namun usaha pengendalian dengan cara ini dapat menimbulkan resistensi jamur patogen sehingga tanaman menjadi lebih mudah terserang penyakit tanaman (Metusala, 2007). Akibat adanya dampak negatif yang ditimbulkan oleh penggunaan metalaksil tersebut, maka perlu dicari alternatif pengendalian yang efektif. Teknik pengendalian yang saat ini sedang banyak diteliti dan dikembangkan adalah penggunaan organisme yang bersifat antagonis. Salah satu antagonis yang banyak diteliti dalam kaitannya sebagai agen pengendalian biologi adalah jamur Trichoderma spp., dan bakteri Pseudomonas fluorescens. Trichoderma spp. merupakan jamur antagonis yang sangat penting untuk pengendalian hayati. (Wibowo et al., 2003).

Salah satu spesies Trichoderma yang mempunyai potensi yang cukup besar dan efektif sebagai agen pengendali hayati adalah Trichoderma viride. Penelitian yang dilakukan oleh Lien A. (1994) dan rekannya dalam Suwahyono (2010), tampak memberikan informasi lebih jelas mengenai proses mekanisme antibiosis dari substansi aktif yang dihasilkan oleh jamur $T$. viride yang dapat menghambat petumbuhan patogen Rizoctonia solanii.

Bakteri P. fluorescens telah dikenal memiliki kemampuan antagonisme yang dapat menekan perkembangan beberapa jamur patogenik dan bakteri patogenik tanaman. Hasil pengujian Stefania (1998) menunjukkan bahwa $P$. fluorescens efektif dalam menekan intensitas serangan penyakit layu fusarium serta meningkatkan pertumbuhan tanaman kapas. 
Pengendalian hayati yang juga banyak diteliti adalah pengendalian dengan mekanisme ketahanan penyakit terimbas. Ketahanan penyakit terimbas merupakan proses ketahanan aktif yang tergantung pada penghalang fisik atau kimia tanaman inang, yang diaktifkan oleh agensia biotik atau abiotik (Soesanto, 2008). Semua tanaman mempunyai mekanisme pertahanan aktif melawan serangan patogen (Van Loon et al., 1998). Setiap tanaman mempunyai pertahanan mekanis dan kimia yang dapat mencegah infeksi (Sastrahidayat, 1990). Selain itu, ketahanan tanaman dapat terbentuk karena mekanisme agensia pengendali hayati yang mampu menurunkan jumlah infeksi patogen dan membatasi pertumbuhan patogen selama tahap parasit di dalam tanah (Soesanto, 2008).

Penelitian ini bertujuan mengetahui pengaruh jamur T.viride, bakteri $P$. fluorescens, dan kombinasi keduanya terhadap penyakit bulai ( $P$. maydis) pada berbagai varietas jagung melalui perlakuan benih.

\section{BAHAN DAN METODE}

Penelitian ini dilaksanakan di Laboratorium Penyakit Tumbuhan Jurusan Proteksi Tanaman Fakultas Pertanian Universitas Lampung dari bulan Januari sampai dengan Mei 2012. Langkah-langkah dalam pelaksanaan penelitian ini adalah penyiapan media biakan T. viride, Penyiapan Media Biakan P. fluorescens, media tanam, Pembuatan Suspensi T. viride, Pembuatan suspensi $P$. fluorescens, Inokulasi spora $P$. maydis (Inokulasi buatan dan Infeksi alami), Pengamatan dan pengumpulan data (Keterjadian penyakit bulai), serta analisis data.

Penyiapan biakan murni $T$. viride dilakukan di Laboratorium Penyakit Tumbuhan. Biakan murni tersebut diperoleh dari biakan koleksi Laboratorium Penyakit Tumbuhan. Untuk mempertahankan daya antagonismenya, dilakukan reisolasi ke dalam media Potato Dextrose Agar (PDA) dalam cawan petri. Penyiapan biakan murni $P$. fluorescens dilakukan di Laboratorium Penyakit Tumbuhan. Biakan murni tersebut diperoleh dari biakan koleksi Laboratorium Penyakit Tumbuhan. Untuk mempertahankan daya antagonismenya, dilakukan reisolasi ke dalam media King'S B dalam cawan petri.

Media tanam yang digunakan adalah tanah yang dimasukkan kedalam polybag berukuran $5 \mathrm{~kg}$. Selanjutnya polybag yang berisi tanah tersebut diletakkan berdasarkan hasil pengacakan, setiap polybag di tanam 10 benih jagung. Tanah dalam polybag dipertahankan kelembabannya dengan cara disiram dengan air. Dengan demikian diharapkan pertumbuhan tanaman akan baik dan sekaligus menjaga pertumbuhan mikroba tanah.

Suspensi $T$. viride di buat dengan cara mensuspensikan 3 cawan petri biakan $T$. viride yang dimasukkan ke dalam pada 1 liter air steril (aquades) dan gula sebanyak 250 gram. Suspensi $T$. viride dengan kerapatan spora $10^{6} \mathrm{spora} / \mathrm{ml}$ ini digunakan untuk perendaman benih jagung sebelum di tanam, benih di rendam selama 15 menit sebelum di tanam.

Suspensi $P$. fluorescens di buat dengan cara mensuspensikan 2 cawan petri biakan $P$. fluorescens yang dimasukkan ke dalam pada 1 liter air steril (aquades) dan gula sebanyak 250 gram. Suspensi $P$. fluorescens ini akan digunakan untuk perendaman benih jagung sebelum di tanam, benih di rendam selama 15 menit sebelum di tanam.

Inokulasi spora P. maydis dilakukan pada dini hari pukul 02.00-04.00 WIB. Tanaman yang terdapat spora $P$. maydis terlebih dahulu direndam di dengan air gula selama 6 jam, kemudian daun-daun tersebut diserut di dalam ember tersebut pada pukul 02-00. Setelah itu, air dimasukkan ke sprayer yang digunakkan untuk inokulasi ke tanaman jagung. Inokulasi dilakukan pada saat kondisi tanaman lembab dan berembun, karena pada kondisi tersebut diharapkan spora $P$. maydis segera berkecambah dan menempel pada bagian daun tanaman. Inokulasi juga dilakukan dengan menyemprotkan cairan pada titik tumbuh tanaman.

Infeksi alami $P$. maydis dilakukan dengan cara menanam tanaman jagung yang menunjukkan gejala penyakit $P$. maydis sebelum penanaman jagung. Tanaman yang menunjukkan gejala ini di tanam di dalam polybag dan diletakkan di sekitar lokasi plot tanaman jagung. Dengan adanya infeksi alami ini, diharapkan tanaman jagung yang di tanam dapat terinfeksi $P$. maydis melalui bantuan angin.

Pengamatan dilakukan 2 hari sekali, dimulai saat tanaman bergejala. Dari data tersebut kemudian dihitung persentase keterjadian penyakit dengan menggunakan rumus sebagai berikut (Zadoks dan Schein, 1979 dalam Sudarsono dan Ginting, 2003):

$$
K P=\frac{\sum \text { tanaman terserang }}{\sum \text { tanaman seluruhnya }} \times 100 \%
$$

Keterangan :

$\mathrm{KP}=$ Keterjadian Penyakit

Data yang diperoleh diolah statistik dengan menggunakan sidik ragam. Apabila terdapat beda nyata, kemudian dilanjutkan dengan uji Beda Nyata Terkecil (BNT) pada taraf nyata $5 \%$. 


\section{HASIL DAN PEMBAHASAN}

Berdasarkan hasil pengamatan gejala muncul pertama pada hari ke 2 setelah inokulasi $P$. maydis (tanaman berumur 14 hari). Gejala penyakit bulai muncul pada daun-daun yang baru saja membuka berupa bercak klorotis kecil-kecil. Bercak ini berkembang menjadi jalur yang sejajar dengan tulang induk. Jamur penyebab penyakit berkembang menuju ke arah pucuk daun. Pada waktu permukaan daun berembun, miselium membentuk konidiofor yang keluar melalui mulut kulit, kemudian berkembang merata hingga ke seluruh permukaan daun.

Hasil analisis ragam menunjukkan bahwa terdapat pengaruh perlakuan terhadap keterjadian penyakit bulai. Perlakuan yang berpengaruh adalah varietas jagung. Sedangkan perlakuan agensia hayati ( $T$. viride, $P$. fluorescens, dan kombinasi keduanya) tidak menunjukkan pengaruh yang nyata. Demikian pula interaksi antara perlakuan varietas dengan agensia hayati tidak menunjukkan pengaruh yang nyata terhadap keterjadian penyakit bulai.
Hasil uji lanjutan terhadap faktor varietas tanaman jagung menunjukkan adanya perbedaan nyata pengaruh varietas dalam menekan keterjadian penyakit bulai (Tabel 1). Hal ini menunjukkan bahwa varietas jagung memiliki respon yang berbeda terhadap penyakit bulai. Pada Tabel 1 dapat dilihat bahwa dari tiga varietas yang di uji, varietas jagung lokal (VJL) lebih tahan terhadap penyakit bulai dengan keterjadian penyakit $1,250 \%$ pada $14 \mathrm{hsi}$, kemudian diikuti dengan varietas jagung hibrida $(\mathrm{VJH})$ dengan keterjadian penyakit $17,847 \%$. Sedangkan varietas jagung manis (VJM), memiliki ketahanan yang rendah atau sangat rentan terhadap bulai dengan keterjadian penyakit $67.058 \%$. Varietas jagung lokal memiliki ketahanan yang tinggi terhadap penyakit bulai, namun produksi jagung lebih sedikit dibandingkan dengan jagung hibrida dan jagung manis.

Dari hasil uji analisis ragam menunjukkan bahwa penggunaan agensia hayati $T$. viride, dan $P$. fluorescensdan kombinasi keduanya tidak memberikan pengaruh yang nyata terhadap keterjadian penyakit bulai P. maydis. Hal ini berarti agen hayati tidak efektif

Tabel 1. Pengaruh varietas tanaman jagung terhadap keterjadian penyakit bulai pada tiga varietas tanaman jagung

\begin{tabular}{lccccccc}
\hline Varietas & \multicolumn{7}{c}{ Keterjadian Penyakit (\%) } \\
\cline { 2 - 8 } \multicolumn{1}{c}{ Jagung } & $2 \mathrm{hsi}$ & $4 \mathrm{hsi}$ & $6 \mathrm{hsi}$ & $8 \mathrm{hsi}$ & $10 \mathrm{hsi}$ & $12 \mathrm{hsi}$ & $14 \mathrm{hsi}$ \\
\hline VJH & $0,625 \mathrm{~b}$ & $1,944 \mathrm{~b}$ & $3,264 \mathrm{~b}$ & $5,972 \mathrm{~b}$ & $9,306 \mathrm{~b}$ & $15,902 \mathrm{~b}$ & $17,847 \mathrm{~b}$ \\
VJL & $0,000 \mathrm{c}$ & $0,000 \mathrm{c}$ & $0,000 \mathrm{c}$ & $0,000 \mathrm{c}$ & $0,000 \mathrm{c}$ & $0,625 \mathrm{c}$ & $1,250 \mathrm{c}$ \\
VJM & $10,900 \mathrm{a}$ & $30,238 \mathrm{a}$ & $45,476 \mathrm{a}$ & $53,251 \mathrm{a}$ & $58,050 \mathrm{a}$ & $67,058 \mathrm{a}$ & $67,058 \mathrm{a}$ \\
\hline BNT & 5,522 & 8,335 & 10,112 & 10,779 & 10,046 & 10,575 & 10,800 \\
\hline
\end{tabular}

Keterangan: Angka yang diikuti huruf yang sama pada kolom yang sama tidak berbeda nyata berdasarkan uji BNT pada taraf 5\%. VJH = Varietas jagung hibrida, $\mathrm{VJL}=$ Varietas jagung lokal, dan VJM = Varietas jagung manis.

Tabel 2. Persentase keterjadian penyakit bulai yang diaplikasikan dengan agensia hayati T. viride, dan P. fluorescens dan kombinasi keduanya.

\begin{tabular}{lccccccc}
\hline \multirow{2}{*}{ Perlakuan } & \multicolumn{7}{c}{ Keterjadian Penyakit (\%) } \\
\cline { 2 - 8 } & 2hsi & 4hsi & 6 hsi & 8 hsi & $10 \mathrm{hsi}$ & $12 \mathrm{hsi}$ & $14 \mathrm{hsi}$ \\
\hline Pf & $6,051 \mathrm{a}$ & $13,492 \mathrm{a}$ & $17,956 \mathrm{a}$ & $20,271 \mathrm{a}$ & $20,271 \mathrm{a}$ & $23,683 \mathrm{a}$ & $24,609 \mathrm{a}$ \\
Tv & $2,083 \mathrm{a}$ & $8,333 \mathrm{a}$ & $13,425 \mathrm{a}$ & $18,402 \mathrm{a}$ & $25,833 \mathrm{a}$ & $36,527 \mathrm{a}$ & $36,527 \mathrm{a}$ \\
Pf-Tv & $3,263 \mathrm{a}$ & $8,703 \mathrm{a}$ & $15,251 \mathrm{a}$ & $17,632 \mathrm{a}$ & $17,632 \mathrm{a}$ & $24,332 \mathrm{a}$ & $25,998 \mathrm{a}$ \\
K & $3,968 \mathrm{a}$ & $12,380 \mathrm{a}$ & $18,353 \mathrm{a}$ & $22,658 \mathrm{a}$ & $26,071 \mathrm{a}$ & $26,904 \mathrm{a}$ & $27,738 \mathrm{a}$ \\
\hline F 0,05 & tn & th & th & tn & tn & tn & tn \\
\hline
\end{tabular}

Keterangan : Angka yang diikuti huruf yang sama pada kolom yang sama tidak berbeda nyata pada taraf 5\%. Pf $=$ Pseudomonas fluorescens, $\mathrm{Tv}=$ Trichoderma viride, $\mathrm{Pf}-\mathrm{Tv}=$ Kombinasi $P$. fluorescens dan $T$. viride, $\mathrm{K}=$ Kontrol. 
sebagai agen penginduksi ketahanan tanaman jagung melawan penyakit bulai (Tabel 2).

\section{KESIMPULAN}

Kesimpulan yang diperoleh dari hasil penelitian yang telah dilakukan, yaitu tidak ada interaksi yang nyata antara faktor perlakuan (T. viride, $P$. fluorescens, dan kombinasi keduanya) dengan faktor varietas, namun faktor varietas jagung memiliki pengaruh yang nyata terhadap keterjadian penyakit bulai. Varietas jagung lokal (VJL) memiliki persentase keterjadian penyakit bulai yang paling rendah sehingga dapat disimpulkan sebagai varietas yang paling tahan dibandingkan dengan varietas lain yang di uji.

\section{DAFTAR PUSTAKA}

Biro Pusat Statistik. 2010. Produksi Tanaman Palawija Propinsi Lampung. BPS. Bandar Lampung.

Iriany, R. N., T. Muzdalifah, Marsum, M. Dahlan, dan Subandi. 2003. Evaluasi Daya Gabung Karakter Ketahanan Jagung Terhadap Penyakit Bulai Melalui Persilangan Diallel. Penelitian Tanaman Pangan. http:// www.pempropsu.go.id/download.php.html. Diakses pada 17 Juli 2011. $5 \mathrm{hlm}$.

Metusala, D. 2007. Pengenalan Fungisida. http:// www.anggrek.org/index.php. Diakses pada 15 Juli $2011.1 \mathrm{hlm}$

Prabowo, H. E. 2005. Dokumentasi Informasi Pertanian Berkelanjutan. http:// mediatani.wordpress.com/jagung.html. Diakses pada 15 Juli $2011.3 \mathrm{hlm}$.
Sastrahidayat, I.R. 1990. Ilmu Penyakit Tumbuhan. Usaha Nasional, Surabaya. $366 \mathrm{hlm}$.

Soesanto, L. 2008. Pengantar Pengendalian Hayati Penyakit Tumbuhan. Raja Grafindo Persada, Jakarta.

Stefania, K. 1998. Identifikasi Bakteri Rizosper Kelompok Fluorescens dan Uji Efektifitasnya Dalam Menekan Penyakit Layu Fusarium (Fusrium oxyxporum) Pada Tanaman Kapas. Skripsi Fakultas Pertanian dan Kehutanan Universitas Hasanuddin, Makassar. Hal. 35-37.

Subandi, 2001. Aspek Produksi Jagung. http:// www.balitsereal.com/jagung.html. Diakses tanggal 1 Desember $2011.5 \mathrm{hlm}$.

Sudarsono, H dan C. Ginting. 2003. Modul Kuliah Teknik Pengamatan dan Pemantauan Hama dan Penyakit Tanaman. Jurusan Proteksi Tanaman Fakultas Pertanian Unila. Bandar Lampung. $55 \mathrm{hlm}$.

Suwahyono, U. 2010. Cara Membuat dan Petunjuk Penggunaan Biopestisida.Jakarta: Penebar Swadaya. $164 \mathrm{hlm}$.

Van Loon, L.C.,P.A.H.M. Bakker, and C.M.J. Pieterse. 1998. Systemic Resistance induced by rhizosphere bacteria. Annu. Rev. Phytopathol. 36:453-483.

Wibowo, Arif dan Suryanti. 2003. Isolasi dan Identifikasi Jamur-jamur Antagonis terhadap Patogen Penyebab Penyakit Busuk Akar dan Pangkal Batang Pepaya. Jurnal Fitopatologi Indonesia (Vol 7) No. 2: 38-44 pp. 